\title{
Effect of dietary supplementation of raw and extruded grass pea seeds (Lathyrus sativus L.) on activity of pancreatic enzymes in pigs
}

\author{
Małgorzata Kapica ${ }^{1}$, J.L. Valverde Piedra ${ }^{1}$, T. Studziński ${ }^{1}$ \\ and E. R. Grela ${ }^{2}$ \\ 'Department of Animal Physiology, Faculty of Veterinary Medicine, \\ Agricultural University of Lublin \\ Akademicka 12, 20-932 Lublin. Poland \\ 'Institute of Animal Nutrition, Faculty of Animal Science, \\ Agricultural University of Lublin \\ Akademicka 13, 20-932 Lublin, Poland
}

\section{ABSTRACT}

The studies were carried on 24 pigs divided into 4 groups: control and 3 experimental. The pigs were fed for 8 weeks the diets: basic diet (control group) and supplemented with 10\% raw grass pea seeds (group II) or with $10 \%$ raw grass peas seeds plus methionine (group III) and supplemented with $20 \%$ extruded grass pea seeds and methionine (group IV).

The protein content in the pancreas did not differ significanty between mean valeus for control and experimental groups. In the control group the protein content in pancreas amounted 755.00 52.7 $\mathrm{mg} / \mathrm{ml}$, while in the three experimental groups $691.27 \pm 25.55,715.83 \pm 54.84$ and $763.33 \pm 50.62$ $\mathrm{mg} / \mathrm{ml}$, respectively. Proteolytic activity of the pancreatic homogenates was significantly lower in both experimental groups (II and $\mathrm{IlI}$ ) of pigs fed on diets with $10 \%$ raw grass pea seeds. There were no significant differences between the pigs from group IV and control.

Tryspin activity of pancreatic homogenates from pigs of the groups II and III was significantly lower than in control pigs and pigs from group IV.

KEY WORDS: lathyrus seeds, pancreatic enzymes, pigs

\section{INTRODUCTION}

Certain legume seeds are rich in protein and could be utilized as important feed ingredients for animals diets. One of the leguminous plants with a high yield is 
Lathyrus sativus L. (Kerney, 1995). The seeds of Lathyrus sativus are a good source of protein (24-32\%), however they are deficient in tryptophan and methionine compared to soyabean (Grela, 1994; Lambein, 1997).

The utilization of grass pea seeds as a feed crop has been limited partly due to their content of antinutritional substances, mainly proteases inhibitors (Roy et al., 1975; Weder, 1981; Rotter et al., 1991). In order to eliminate these substances the grass pea seeds can be toasted, autoclaved, boiled in water or extruded (Liener, 1983; Rotter, 1990).

The purpose of this work was to evaluate the influence of raw and extruded flat pea seeds supplemented to the diet on the activity of pancreatic enzymes in pigs.

\section{MATERIAL AND METHODS}

The studies were conducted on 24 pigs divided at random into 1 control and 3 experimental groups. The pigs were fed for 8 weeks with the mixtures prepared according to NRC (PT-1). The pigs of the first group (I) were fed an unsupplemented control diet (Table 1). The pigs of the second group (II) were fed on a similar diet plus $10 \%$ raw grass pea seeds, and of the third group (III) on a similar diet plus $10 \%$ of raw grass pea seeds additionally supplemented with methionine (Table 1). The pigs of the fourth group (IV) received a diet containing $20 \%$ of extruded grass pea seeds plus methionine (Table 1). During the experiment all pigs were allowed free access to water. At the end of the feeding stage of the study the pigs were slaughtered and samples of the pancreatic glands were frozen $\left(-20^{\circ} \mathrm{C}\right)$ for further analysis.

TABLE 1

Diet composition

\begin{tabular}{lcccc}
\hline & Control group & \multicolumn{3}{c}{ Groups } \\
Components, \% & (standard diet) & II & III & IV \\
\hline Wheat & 30.0 & 30.0 & 30.0 & 30.0 \\
Barley & 51.0 & 47.0 & 46.9 & 42.9 \\
Extracted soyabcan meal & 13.0 & 7.0 & 7.0 & - \\
Meat-bone meal & 4.0 & 4.0 & 4.0 & 5.0 \\
Limestonc & 0.9 & 0.9 & 0.9 & 0.9 \\
Raw grass pea seeds & - & 10.0 & 10.0 & - \\
Extruded grass pea sceds & - & - & - & 20.0 \\
Methionine & - & - & 0.1 & 0.1 \\
Ekomix PT-1 super & 0.95 & 0.95 & 0.95 & 0.95 \\
Lysine & 0.15 & 0.15 & 0.15 & 0.15 \\
Total & 100.0 & 100.0 & 100.0 & 100.0 \\
\hline
\end{tabular}


Homogenates of pancreatic tissue were analyzed for total protein using the Bradford method (1976). Protcolytic activity was determined spectrophotometrically using casein as substrate. One unit of proteolytic activity was defined as the amount of enzyme that hydrolyzed $1 \mathrm{mg}$ of cascin $/ 20 \mathrm{~min}$ incubation $/ \mathrm{mg}$ protein. The trypsin activity was measured using a micromodification of the original method of Erlanger et al. (1961), consisting in longer time of incubation. The trypsin activity was expressed as units (U) and defined as the amount of enzyme that hydrolyzed $1 \mu \mathrm{mol}$ of substratc (N-Benzoyl-L-Arginine-4-Nitroanilide Hydrochloride) $/ 15 \mathrm{~min} / \mathrm{mg}$ of protein. The amylolytic activity was determined by the method described by $O^{\prime}$ Sullivan (1992). The activity of amylase was expressed as units $(\mathrm{U})$ and calculated in $\mu \mathrm{mol}$ of maltose released from starch solution.

The results were statistically analysed using Students t-test.

\section{RESULTS AND DISCUSSION}

There were no significant differences in the protein content of the pancreatic homogenates between the control and any of the expcrimental groups. In the control group the protein content amounted to $755.00 \pm 52.7 \mathrm{mg} / \mathrm{ml}$, while it was $691.27 \pm 25.55,715.83 \pm 54.84$ and $763.33 \pm 50.62$ in the three experimental groups, respectively (Table 2 ).

The proteolytic activity of the pancreatic homogenates was, however, significantly lower in both groups (II and III) of pigs fed on the diet supplemented with raw grass pea seeds than in the control (Table 2). In contrast, there was no difference between the pigs of control group I and the pigs of group IV fed on extruded grass pea seeds.

Similarly, the trypsin activity of pancreatic homogenates from pigs of group II and III were significantly lower than those of control group I or experimental group IV (Table 2). There were no differences in amylolytic activity of the pancreatic homogenates between any of the groups (Table 2).

TABLE 2

Protein content and enzyme activity in pancreatic homogenates

\begin{tabular}{lcccc}
\hline & \multicolumn{4}{c}{ Groups } \\
\cline { 2 - 5 } & I & II & III & IV \\
\hline Protein, $\mathrm{mg} / \mathrm{ml}$ & $755.00 \pm 52.7$ & $691.67 \pm 25.55$ & $715.83 \pm 54.84$ & $763.33 \pm 50.62$ \\
Proteolytic activity, U/mg protein & $3.27 \pm 0.45$ & $1.62^{*} \pm 0.53$ & $1.77^{*} \pm 0.24$ & $4.35+0.44$ \\
Trypsin activity, U/mg protein & $9.43 \pm 1.8$ & $2.23^{* *} \pm 0.23$ & $2.55^{* *} \pm 0.14$ & $7.44 \pm 0.95$ \\
Amylase activity, $\mu \mathrm{mol} / \mathrm{mg}$ protein & $394.1 \pm 49.3$ & $487.6 \pm 28.7$ & $316.8 \pm 31.86$ & $450.8+41.72$ \\
\hline
\end{tabular}

$*=\mathrm{P}<0.05$, experimental vs. control

$* *=\mathbf{P}<0.0$ I, experimental vs. control 
The results obtained indicate that dietary supplementation of grass pea seed has an inhibitory influence on pancreatic enzymatic activity in pigs. The most evident inhibitory influence, on proteolytic and tryptic activity was observed in the pigs of groups II and III, which were fed on a diet supplemented with $10 \%$ of raw grass pea seeds. These results indicate the presence of antinutritional substances (factors) directed selectively at the proteolytic enzymes of the pancreas. Evidence for such an explanation was given by the results obtained from the pigs of the IV group, which were fed on the diet supplemented with extruded grass pea seeds as well as by the lack of influence of the grass pea seeds (antinutritional substances) on amylolytic activity. This is in agreement with separate and nonparallel pancreatic enzyme synthesis and secretion.

\section{CONCLUSIONS}

Dietary supplementation with grass pea seeds for 8 weeks inhibits proteolytic and tryptic activity of the pancreas in finishing pigs.

Extrusion of grass pea seeds eliminates these inhibitory effects on pancreatic proteolytic and tryptic activity.

Dietary supplementation for 8 weeks of raw or extruded grass pea seeds has no influence on pancreatic amylase activity.

\section{REFERENCES}

Bradford M.M., 1976. A rapid and sensitive method for quantitation of microgram quantities of protein utilizating the principle of protein dye binding. Anal. Biochem. 72, 248-254

Erlanger B.F., Kokowsky N., Cohen W., 1961. The preparation and properties of two new chromogenic substrates of trypsin. Arch. Biochem. Biophys. 95, 271

Grela E., 1994. Chemical composition and nutritive value of lathyrus seeds (in Polish). Prz. hod. 62 (2), $9-11$

Kay D., 1976. Crop and Product Digest. Food Legumes. Tropical Product Institute, London, No 3, pp. 115

Kearney J., Smartt J., 1995. The grasspea - Lathyrus sativus (Leguminosae-Papilionoideae). In: J. Smartt, N.W. Simmonds (Editors). Evolution of crop plants. Longman, London, pp. 266-270

Lambein F., Kuo Y-H., 1997. Lathyrus sativus, a neolithic crop with a modern future? An overview of the present situation. Proceedings of International Scientific Symposium, Lathyrus sativus cultivation and nutritive value in animals and humans. Lublin-Radom, Poland, pp. 6-12

Liener I.E., 1983. Chemistry and World Food Supplies: The New Frontiers. New York, Pergamon Press, pp. 453-63

O'Sullivan N.P., 1992. Correlated responses in lines of chickens divergently selected for fifty-sixday body weight. 3. Digestive enzymes. Poultry Sci. 71, 610-617

Rotter R., Marquardt R., Campbell C., 1991. The nutritional value of low lathyrogenic lathyrus (Lathyrus sativus) for growing chicks. Brit. Poultry Sci. 32, 1055 
Rotter R., Marquardt R., Low R., Briggs C., 1990. Influence of autoclaving on the effects of Lathyrus sativus fed to chicks. Can. J. Anim. Sci. 70, 739

Roy D., Bhat R., 1975. Variation in neurotoxin, trypsin inhibitors and susceptibility to insect attack in varietes of Lathyrus sativus seeds. Environ. Physiol. Biochem. 5, 172

Weder J.K.P., 1981. Protease inhibitors in the Leguminosae. R.M. Polhill, P.H. Raven (Editors). Advances in legume systematics. Part 2. Royal Botanic Gardens, Kew, pp. 533-560 